This item was submitted to Loughborough's Research Repository by the author.

Items in Figshare are protected by copyright, with all rights reserved, unless otherwise indicated.

\title{
Miracle near 34th street: Wartime penicillin research at St John's University, NY
}

PLEASE CITE THE PUBLISHED VERSION

https://doi.org/10.1016/j.endeavour.2017.09.003

PUBLISHER

(C) Elsevier

VERSION

AM (Accepted Manuscript)

PUBLISHER STATEMENT

This paper was accepted for publication in the journal Endeavour and the definitive published version is available at https://doi.org/10.1016/j.endeavour.2017.09.003

LICENCE

CC BY-NC-ND 4.0

\section{REPOSITORY RECORD}

Shama, Gilbert. 2017. "Miracle Near 34th Street: Wartime Penicillin Research at St John's University, NY". figshare. https://hdl.handle.net/2134/27139. 
Miracle near $34^{\text {th }}$ Street: Wartime Penicillin Research at St John's University, NY.

\section{Gilbert Shama}

Department of Chemical Engineering, Loughborough University, Loughborough, Leicestershire LE11 3TU, UK.

In the spring of 1944 Sister Marie Immaculate was awarded a Master of Science degree for research on penicillin which she had conducted at St John's University in Brooklyn, New York. She gave her motivation for undertaking research in this topic as wishing to fulfil her patriotic duty by participating in the quest towards making penicillin more readily available to all who needed it. It is possible that contemporary media reports suggesting that the power of penicillin was comparable to a miracle cure contributed to her interest in the subject at the time. In practical terms, her work was to have no bearing in increasing the availability of penicillin, but simply by becoming engaged in this endeavour, it could be argued that she was enacting the beliefs underlying her religious calling. This article explores those beliefs, and proposes an ideological synergy between science and religion in respect to Sister Marie Immaculate's faith in penicillin's potential to cure the world's ills.

The first mention of penicillin in both the British and American national press appeared towards the end of $1940 .^{1}$ Early accounts were restrained in tone, and simply supported speculation that penicillin might eventually come to supersede the sulphonamides - the only effective antibacterial chemotherapeutic agents then available. Thereafter, references to penicillin in the press grew exponentially, peaking in 1944 on both sides of the Atlantic. With time, and as clinical evidence for the effectiveness of penicillin accumulated, the tone of such reports was to undergo a dramatic change, and the terms 'miracle' and 'miraculous' were to be increasingly applied to descriptions of its capabilities. Such reports were not restricted to the national press, but found their way into a wide variety of publications: to cite just one example one item on penicillin in a woman's journal was entitled 'Miracle from

Corresponding author: G.Shama@Lboro.ac.uk

1'A New 'Sulfanilamide.' The New York Times, 20 October 1940, p.57.'Hope of a New Drug.' The Scotsman, 23 November 1940, p. 9. 
Mold'. ${ }^{2}$ Still wider promulgation of news about the development of penicillin was achieved through radio broadcasts. ${ }^{3}$

A variety of approaches were adopted to convey to the public at large the powerful antibacterial properties of penicillin in terms that is was assumed they would comprehend. For instance, in a BBC broadcast transmitted in the spring of 1944 featuring Alexander Fleming, he made reference to the highest dilution that pure penicillin could undergo and still retain the power to inhibit bacterial growth. ${ }^{4}$ Fleming stated that the dilution factor was 80 million, but acknowledged that his audience might have difficulty in making sense of such a large figure. To assist them in this, he informed listeners that this was akin to diluting a drop of water 100 million times, and that to do so would require 5,000 litres, which was equivalent to the contents of 7,000 whisky bottles or 9,000 bottles of milk. It seems probable that a proportion of the radio audience, comprising both habitual drinkers and teetotallers alike, would have formed a realistic assessment of penicillin's potent antibacterial properties from Fleming's example. But even for those who may have struggled with the concept, references to such high figures (thousands and millions) may have provided an indication of the drug's impressive potential.

In 1943, coupled with accounts of penicillin's success in overcoming a wide range of bacterial infections, was the news that all production of the antibiotic was to be reserved exclusively for the armed forces. Perhaps understandably, this led to a feeling of frustration amongst the general public, and the archival papers of many of the individuals identified in press accounts as being involved in the development of penicillin as a chemotherapeutic agent, contain desperate pleas from relatives and friends of the sick for access to it. ${ }^{5}$ It is clear to the contemporary scientist that many of the medical conditions described in the archived documents would simply not have been treatable with penicillin. Rather, they indicate that penicillin was taking on the character of a panacea in the mind of the public - a 'cure for all', especially considering the sheer variety of medical complaints presented. In the public consciousness it appeared that here was at last a chemotherapeutic agent that met La Feu's claim in All's Well that Ends Well to 'have seen a medicine that's able to breathe life into a stone, quicken a rock... ${ }^{6}$

The sense of frustration felt by members of the public was evidently relayed by them to both medical practitioners and pharmacists, and in fact prompted a handful of such individuals, both in Britain and the United States, to meet the clamour for penicillin by undertaking the small scale manufacture of crude penicillin preparations themselves. However, given the limitations imposed upon them by wartime

\footnotetext{
2 'Miracle from Mold.' Woman's Home Companion, September 1943, pp.70-3.

${ }^{3}$ Shama G, Auntiebiotics: the BBC, penicillin and the Second World War. Brit Med J. 2008; 337: article number a2746.

${ }^{4}$ BBC Broadcast. Science Notebook - Chapter 67. 7 April, 1944.

${ }^{5}$ To cite just one example, The Howard Florey archive, The Royal Society, London.

${ }^{6}$ Shakespeare, W. All's Well that Ends Well, Act 2, scene 1.
} 
shortages, these endeavours had negligible practical benefits. ${ }^{7}$ One whose name has hitherto not featured in such accounts is that of Sister Marie Immaculate (Helen Marie Tobin, 1906-1999).

Sister Immaculate held a teaching post in Brooklyn Catholic High Schools when she began her research in penicillin under the supervision of Professor Edward $\mathrm{J}$. Keegan, Chairman of the Biology Department at St John's University, in April 1943.This was a time when, as mentioned previously, press coverage of news about penicillin was growing exponentially. It seems reasonable to suppose that the publicity surrounding penicillin played a part in her decision to undertake research in this particular field. If she had not encountered such reports first hand, she would almost certainly have heard about them from others, including from her supervisor.

As a registered student at St John's, Sister Immaculate would have become well versed with the teachings of St Vincent de Paul whose convictions - that one finds God and oneself in service to others - constitute the guiding principles at the core of St John's mission. ${ }^{8}$ These can be seen as underlying what she refers to in her thesis as her inspiration for undertaking research on penicillin, namely, as meeting 'a patriotic desire to further its progress as a contribution to the war effort.' ${ }^{9}$ The main thrust of her research was to show that a variety of readily available foodstuffs could serve as a source of nutrients for the Penicillium notatum mold. However, she withheld from publishing in her thesis details of the compositions of the growth media she used in her experiments. The reason Sister Immaculate gave for not doing so being the sensitivity of the work being undertaken in wartime. Further information on this may be gleaned from interviews she and her supervisor gave to newspaper reporters at the time, these were occasionally accompanied by images such as that shown in Figure 1. For example, in one report it was claimed that she had discovered 'that penicillin can be developed from almost any edible foodstuff containing protein, carbohydrates and butter salts'. ${ }^{10}$ Her use of ordinary foodstuffs as a growth medium for the Penicillium mold could also be interpreted as seeking to effect a transubstantiation of sorts, equivalent to those of the sacrament of the Eucharist, with bread as the body of Christ. A strong Eucharistic element can also be found in the 'bread of life discourse' that appears in the Gospel According to John. ${ }^{11}$ In Sister Immaculate's case, the 'feeding' of the five thousand becoming transliterated as her desire to supply penicillin to an unspecified, but certainly significant, number of sick people.

\footnotetext{
${ }^{7}$ Shama G. The role of the media in influencing public attitudes to penicillin during WW II.Dynamis. 2015;35:131-152.

${ }^{8}$ http://www.stiohns.edu/faith-service/our-mission. [Accessed 25/08/17]

9 Toibin HM. Penicillin, an Antibiotic Produced by Mold. MS Thesis: University of St. John's, N.Y. 1944.

10 Nuns' Research on Penicillin The Catholic Herald 3 March 1944, p. 6.

11 The Gospel According to St. John, 6, 25-71.
} 
One press account makes reference to the fact that Sister Immaculate had added brandy and corn liquor to her growth media. ${ }^{12}$ There would appear to be two possible reasons for the incorporation of such ingredients. The first relating to the discovery by Andrew Moyer, based at the USDA laboratories in Peoria, Illinois, that the addition of corn steep liquor (CSL) led to a dramatic increase in penicillin yields. ${ }^{13}$ However, this reveals a misinterpretation of what CSL is; it is in fact a concentrate produced from the water in which corn has been steeped in, in order to facilitate its milling into flour. It contains no alcohol whatsoever, and the ingredient in CSL subsequently found to increase penicillin yields was the amino acid phenylacetate. Without information on the quantities of such liquors that she employed it is difficult to assess in practical terms what effect this may have had on either the growth of the mold or its ability to produce penicillin. However, no subsequent work has attested to the benefits of adding alcohol, even in low concentrations, to growth media for penicillin production. The second, - somewhat more spiritual influence (in the nonalcoholic sense of the term), could be seen as an additional re-enactment of Eucharist, and its allusion to the blood of Christ. Presumably brandy served as a substitute for corn liquor; the connection with the Eucharist being that it is produced from the distillation of wine. Whilst in the Catholic religion only priests and bishops have the power to consecrate the bread and wine employed during Mass, it seems reasonable to suppose that Sister Immaculate received the necessary authority to introduce these ingredients into Penicillium growth media from her secular superior, Professor Keegan. Equally, she may have inherited the confusion of CSL with alcoholic liquors from Keegan, putting into question the doctrine of research supervisor infallibility. The first direct association between the rituals of Eucharist with healing was made in the $2^{\text {nd }}$ Century by St. Ignatius of Antioch, who in his epistle to the Ephesians describes the Eucharist as 'the medicine of immortality, the antidote against death'. ${ }^{14}$

In a study conducted in the late 1990s in which antibiotic use in two cities, one Belgian, the other Dutch was compared, it was found that more prescriptions for antibiotics were issued in the Belgian city where notably, the population was predominantly Catholic. The authors attributed this to the fact that 'in Catholicism rituals with tangible objects like sacraments play a central role,' whereas they ascribed the lower consumption of antibiotics among Protestant participants in the

\footnotetext{
12 '3 Nuns get Penicillin from Food.' New York Herald Tribune, 17 December 1943, p. 12.

${ }^{13}$ For reasons of security the effect of CSL on penicillin yields was only published after the war, but this information was widely circulated among pharmaceutical companies engaged in the production of penicillin. It is revealed later in this piece that links existed between Pfizer and St. John's University. Moyer, A. J., \& Coghill, R. D. (1946). Penicillin: VIII. Production of Penicillin in Surface Cultures 1.Journal Bact.1946;51, 57-78.

${ }_{14}$ Srawley JH, The Epistles of St. Ignatius, (Society for Promoting Christian Knowledge: London, 1900), p. 51.
} 
trial as a combination of greater faith in the body's ability to repair itself, and to 'nursing one's own illness'. ${ }^{15}$

Sister Immaculate must surely have been motivated in her work by looking forward to a time when penicillin could simply be allocated to those in need of it. This concept is referred to in Catholicism as anamesis - an anticipation of ultimate fulfilment. An act in which, as Deschepper et al. put it, 'a pill could be seen as a secularised counterpart of the sacraments that can ensure salvation'. ${ }^{15}$

The miracle Sister Immaculate sought to perform at St. John's failed to materialise. It is relevant to point out here that another - related - miracle at a location approximately the same distance from $34^{\text {th }}$ Street as is the Brooklyn campus of St John's, and at roughly the same period in time, did come to pass. This was the installation by the Pfizer Company of large scale fermentation vessels for the production of penicillin by submerged fermentation. ${ }^{16}$ These vessels were located in a former ice works belonging to the Rubel Company, situated in the SW corner of Morgan Avenue and Maujer Street. The 'miracle' in this case being that the installation of the vessels dramatically improved the rate at which penicillin could be produced. Moreover, there is a connection between the two; since in her thesis Sister Immaculate thanks the Pfizer Company for having supplied her with the strain of $P$. notatum that she used in her work. The aims of both Sister Immaculate and Pfizer, as proposed instigators of would be miracles, were therefore aligned. Overall, the new development by Pfizer was to have a profound effect in making penicillin more widely available at a time of desperate need. However, it could be argued that the fact that Sister Immaculate's attempt was to have no real tangible impact, should not take away from the righteousness of her intent.

The association of penicillin with the miraculous has even earlier antecedents than those under discussion here. For instance, in his biography of Alexander Fleming, André Maurois writes that once Fleming's isolate had been correctly identified as a strain of Penicillium notatum by the mycologist Charles Thom (and not $P$. rubrum as Charles La Touche had originally classified it), Fleming learnt that the type strain of $P$. notatum had been isolated from a specimen of decayed hyssop by the Swedish chemist Richard Westling. As this dawned upon him, the following lines from the Book of Psalms entered his mind: 'Purge me with hyssop, and I shall be clean: wash me, and I shall be whiter than snow.' ${ }^{17}$ There may, therefore, be some validity in referring to Fleming's original observation as 'Miracle on Praed Street' or, better still,

\footnotetext{
${ }^{15}$ Deschepper R., Vander Stichele RH, Haaijer-Ruskamp FM, Cross-cultural differences in lay attitudes and utilisation of antibiotics in a Belgian and a Dutch city Patient EducCouns. 2002;48:161169.

${ }^{16}$ American Chemical Society. Development of Deep-tank Fermentation. https://www.acs.org/content/acs/en/pressroom/newsreleases/2008/june/pfizers-work-on-penicillin-forworld-war-ii-becomes-a-national-historic-chemical-landmark.html [Accessed 14.07.17].

17 Maurois A. The Life of Sir Alexander Fleming, (Jonathan Cape: London, 1959), p. 35, The Book of Psalms, Psalm 51, verse 7.
} 
given the theme of this piece, 'Miracle at St. Mary's.' It has become the accepted view that Fleming essentially abandoned all activity on penicillin after the early 1930s, but Milton Wainwright has long campaigned against this interpretation. ${ }^{18}$ Indeed, who is to say that these words, which would prove to be an accurate portent of what was to follow, did not remain with Fleming and continue to motivate him? An artistic interpretation of Fleming's penicillin epiphany is to be found in a stained glass panel in St. James' Church, Paddington (Fig. 2).

A much deeper understanding of the modes of action of antibiotics has been achieved in the decades following World War II. Alongside these developments has been the steady emergence of pathogenic bacteria, resistant firstly to penicillin, and subsequently to the entire armentarium of existing antibiotics. This, combined with the low rate at which new classes of antibiotics are being isolated, is often framed using a discourse of catastrophe; the terms 'post-antibiotic apocalypse' and even 'pharmageddon' have been widely used in this context. ${ }^{19}$ Furthermore in her analysis of the discourse used in accounts warning of the consequences of the rise of socalled 'superbugs' Nerlich proposes that the term 'apocalypse' has been borrowed from the rhetoric used to describe fears over global warming. ${ }^{20}$ Whilst there is some validity to this claim, the use of this term in particular bears a more direct connection with fears that, in the future, we shall be deprived of recourse to chemotherapeutic agents which are still to this day viewed as possessing miraculous powers. ${ }^{21}$

\section{Figure Captions}

(Fig. 1) Sister Immaculate (foreground) assisted in her research by Sister Agnes Jean. Also present is Professor Edward J Keegan - their supervisor, December 1943.St. John's University Archives, Queens NY.

(Fig. 2) Stained glass panel depicting Alexander Fleming, St James's Church Sussex Gardens, Paddington, London.

\footnotetext{
${ }^{18}$ Wainwright M. Fleming's Unfinished. PerspectBiol Med. 2002;45:529-538.

${ }^{19}$ Cox JAG, Worthington T. The 'antibiotic apocalypse'- scaremongering or scientific reporting? Trends Microbiol. 2017;25:167-169. Anon. Pharmageddon. Microbiologist. 2002;3:16.

20 Nerlich B., "The post-antibiotic apocalypse" and the "war on superbugs". Catastrophe discourse in microbiology, its rhetorical form and political function. Public Understand Sci. 2009;18: 574-590.

${ }^{21}$ Bartlett JG, Gilbert DN, Spellberg B., Seven ways to preserve the miracle of antibiotics. Clin Infect Dis. 2013;56:1445-1450.
} 
Figure 1

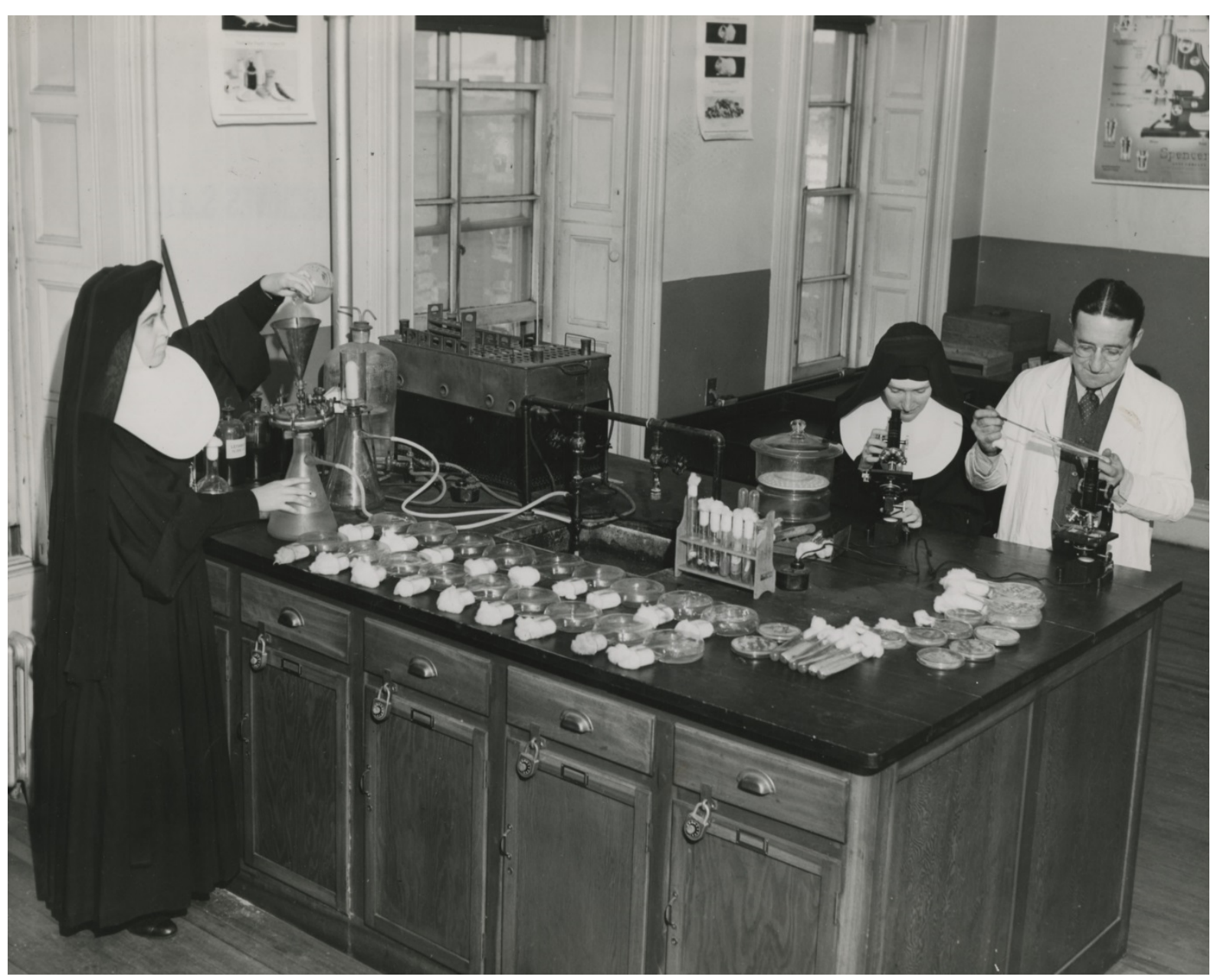


Figure 2

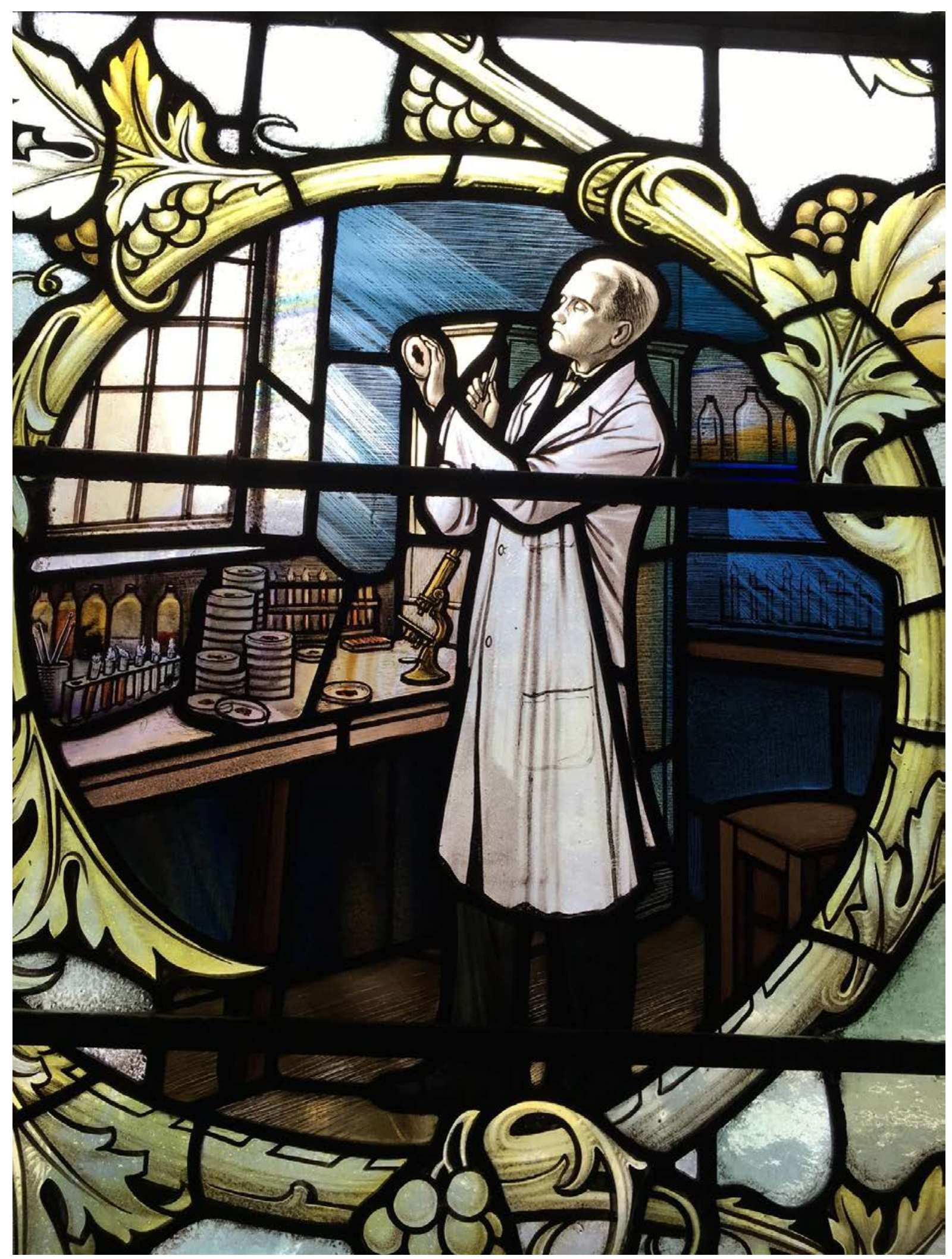

